\title{
KONTRIBUSI ROYALTI PT NEWMONT NUSA TENGGARA TERHADAP PENDAPATAN DAERAH KABUPATEN SUMBAWA BARAT TAHUN 2006-2012
}

\author{
Subhan Purwadinata ${ }^{1}$ \\ ${ }^{1}$ Universitas Samawa, Indonesia \\ Email:123adinata@gmail.com
}

\begin{abstract}
Abstrak
The purpose of this study was to investigate the contribution of royalty PT NNT to the regional income West Sumbawa. In this study, secondary data on the realization of royalty PT NNT and regional income data for the year 2006-2012. The data comes from the offices of the financial revenues of West Sumbawa. This study uses a quantitative approach simple statistics. The results of this study indicate that the variable royalty contribute positively to regional income West Sumbawa regency in 2006-2012. This is indicated by the value of the contributions made by the variable royalty PT NNT to the regional income Sumbawa district from 2006 amounted to $21.70 \%$, in 200713.69 decreased in 2008 decreased 1.05 percent from the year 2008 amounted to 12.64 percent, Then in 2009 the contribution of royalty PT NNT rose 13.78 percent and in 2010, 2011 and 2012 contributions amounting to 11.56 percent and 08.16 percent. The conclusion from this study is that the variable royalty $P T$ Newmont Nusa Tenggara has contributed greatly to the increase of regional income West Sumbawa regency during 2006-2012.
\end{abstract}

Keywords: Royalties, Local Revenue JEL Classification: O14, 018

\section{PENDAHULUAN}

\section{Latar Belakang}

Untuk menentukan rencana pembangunan ekonomi suatu Negara atau daerah diperlukan bermacammacam data dan kemampuan untuk mengolahnya sehingga dapat menghasilkan informasi-informasi penting sebagai dasar penentuan strategi dan kebijakan agar sasaran yang ditetapkan dapat dicapai dengan tepat. Strategi dan kebijkan pembangunan ekonomi yang telah diambil pada masa-masa yang lalu perlu dimonitor dan dilihat hasil-hasilnya. Berbagai data yang merupakan ukuran kuantitas, mutlak diperlukan untuk memberikan gambaran tentang keadaan pada masa yang lalu dan masa yang akan datang (Hartono, 1999).

Pembangunan bidang ekonomi berupaya menciptakan partumbuhan ekonomi daerah yang cukup tinggi, sekaligus mewujudkan struktur perekonomian daerah yang ada menjadi struktur perekonomian yang terus tumbuh dan berkembang serta tangguh. Dengan demikian, diharapkan dapat menciptakan lapangan kerja yang lebih luas dan meningkatkan pendapatan masyarakat yang lebih merata. Salah satu data yang dapat digunakan untuk melihat kemajuan pembangunan ekonomi dan hasil yang telah dicapai tersebut adalah APBD yaitu indikator yang menunjukkan kemampuan suatu daerah untuk menghasilkan atau menciptakan pendapatan dan mengetahui 
pengeluaran yang telah direalisir pada suatu periode/tahun tertentu (Hartono, 1999).

Perencanaan pembangunan daerah merupakan perencanaan yang integratif dan komprehensif, artinya bahwa penentuan dan pemilihan prioritas didasarkan kebutuhan masyarakat yang dalam implementasinya perencanaan pembangunan daerah harus mengaitkan ke seluruh sektor sosial dan ekonomi serta mengacu pada kebijakan nasional. Jadi perencanaan pembangunan pada dasarnya berkaitan dengan proses pengambilan keputusan tentang bagaimana cara terbaik untuk mendapatkan sumber daya optimal dalam rangka mencapai tujuan dan sasaran pembangunan, menjadi program-program pembangunan daerah yang kemudian disusun berdasarkan skala prioritas yang telah ditetapkan dengan mengacu pada sasaran dalam Propeda(Hartono,1999)

PT Newmont Nusa Tenggarra (PT.NNT) merupakan perusahaan patungan yang sahamnya dimiliki oleh Nusa Tenggara Partnership (Newmont dan Sumitomo), PT Pukuafu Indah (Indonesia) dan PT Multi Daerah Bersaing. Newmont dan Sumitomo bertindak sebagai operator. PT NNT menandatangani kontrak karya pada tahun 1986 dengan pemerintah Republik Indonesia untuk melakukan eksplorasi dan eksploitasi di dalam wilayah kontrak karya di Propinsi Nusa Tenggara Barat. PT NNT menemukan cebakan tembaga porfiri pada tahun 1990, yang kemudian diberi nama Batu Hijau. Setelah penemuan tersebut, dilakukanlah pengkajian teknis dan lingkungan selama enam tahun. Kajian tersebut disetujui pemerintah Indonesia pada tahun 1996 dan menjadi dasar dimulainya pembangunan proyek tambang Batu Hijau dengan total investasi US\$1,8 Miliar. Proyek pem- bangunan tambang, pabrik dan prasarananya selesai pada tahun 1999 dan mulai beroperasi secara penuh pada bulan Maret tahun 2000 sampai sekarang.

Sejalan dengan era globalisasi daerah dituntut untuk lebih siap lagi dalam mempersiapkan sarana dan prasarana terutama infrastruktur yang memadai, semua kepentingan ini tentunya akan membutuhkan dana yang semakin besar pula. Oleh karena itu, upaya untuk meningkatkan sumbersumber penerimaan daerah harus selalu mendapatkan perhatian yang lebih serius. Beberapa pemikiran tersebut memberikan motivasi untuk melakukan penelitian dan menganalisis tentang kontribusi Royalti PT Newmont Nusa Tenggara terhadap pendapatan daerah.

\section{Rumusan Masalah}

Berdasarkan uraian latar belakang di atas maka dapat dipaparkan rumusan yang menjadi inti permasalahan yang diteliti adalah sebagai berikut bagaimana besarnya Kontribusi Royalti PT Newmont Nusa Tenggara terhadap Pendapatan Daerah Kabupaten Sumbawa Barat Tahun 20062012 ?

\section{Asumsi Penelitian}

dasar $\begin{gathered}\text { Asumsi adalah anggapan } \\ \text { yang berfungsi untuk }\end{gathered}$ mempertegas objek atau subjek kajian dalam penelitian. Penggunaan asumsi dalam penelitian umumnya dimaksudkan agar pembatasan masalah dalam penelitian menjadi lebih jelas. Adapun asumsi-asumsi yang digunakan dalam penelitian ini adalah variabel lain dalam hal ini DAU, DAK, DBH serta PAD di Kabupaten Sumbawa Barat dianggap tetap atau cateris paribus. 


\section{Tujuan Penelitian}

Adapun tujuan dari penelitian ini adalah untuk mengetahui Kontribusi royalti PT Newmont Nusa Tenggara terhadap Pendapatan Daerah Kabupaten Sumbawa Barat Tahun 2006-2012.

\section{Manfaat Penelitian}

Adapun manfaat dari penelitian ini secara praktis yaitu untuk memberikan sumbangan pemikiran kepada masyarakat dan menambahkan pengetahuan dan informasi sebagai bahan kajian bagi penelitian selanjutnya terhadap PT NNT dan Pemerintah Daerah Kabupaten Sumbawa Barat.

\section{TINJAUAN PUSTAKA DAN HIPOTESIS}

\section{Teori Pendapatan}

Pendapatan adalah merupakan nilai dari keseluruhan produksi dalam perekonomian yang diperoleh dengan menjumlahkan pendapatan seluruh faktor produksi yang digunakan dalam proses produk-si (Hartowo,1984). Berdasarkan pendapat tersebut yang dimaksud dengan pendapatan dalam penelitian ini adalah pendapatan petani dalam kaitan dengan konsumsi masyarakat petani. Pendapatan kotor yaitu pendapatan yang diperoleh sebelum dikurangi biaya sedangkan pendapatan bersih merupakan pendapatan yang diperoleh setelah dikurangi biaya.

Dalam hal pembagian pendapatan akan disesuaikan dengan faktor produksi apa yang diberikan kepada pemakai. Apabila faktor produksi yang diberikan kepada pemakai. Apabila faktor produksi yang diberikan berupa tanah, maka akan memperoleh sewa tanah, apabila yang diberikan berupa modal, maka akan memperoleh bagian berupa bunga modal, apabila berupa tenaga kerja maka akan memperoleh bagian berupa bunga modal, apabila berupa tenaga kerja maka akan memperoleh upah/gaji dan apabila berupa kewirausahaan maka akan memperoleh laba (Sumitro,1986)

Pembagian pendapatan dibagi menjadi beberapa cara yaitu (1) pendapatan ditinjau dari sudut golongan produksi, faktor penerimaan pendapatan seperti : buruh untuk faktor produksi tenaga kerja yang menerima upah, tanah diterima sewa tanah, modal diterima bunga modal, serta pengusaha yang menerima keuntungan (2) pendapatan ditinjau dari sudut fungsi individu dalam produksi (3) pendapatan ditinjau dari besarnya pendapatan yang diperoleh dari masingmasing individu.

Sedangkan dalam menghitung pendapatan bersih perusahaan, maka harus pula diketahui seberapa besar biaya atau pengeluaran yang dikeluarkan. Pengertian biaya dalam penelitian ini adalah keseluruhan biaya yang dikeluarkan oleh petani dalam memproduksi padi yang dihasilkan dan konsep pengeluaran dipakai dalam kaitannya dengan produksi.

\section{Teori Kontribusi}

Kontribusi merupakan share atau sumbangan yang diberikan oleh setiap daerah terhadap Kebijakan keuangan daerah diarahkan untuk meningkatkan Pendapatan sendiri sebagai sumber utama pendapatan daerah. Sumber itu dapat dipergunakan daerah sesuai dengan kebutuhannya. Dari berbagai jenis pendapatan daerah yang memberikan kontribusi terbesar bagi pembangunan.

Daerah otonom harus memiliki kewenangan dan kemampuan untuk menggali sumber-sumber keuangan sendiri, mengelola dan menggunakan keuangan sendiri yang cukup mema- 
dai untuk membiayai penyelenggaraan pemerintahan daerahnya. Ketergantungan kepada pemerintah pusat harus seminimal mungkin, sehingga pendapatan harus menjadi sumber keuangan yang terbesar yang didukung oleh kebijakan perimbangan keuangan pemerintah pusat dan daerah sebagai pra syarat mendasar dalam sistem pemerintahan negara yang kontribusi yang besar (Koswara, 2000).

Kemampuan aparat pemerintah daerah di bidang akuntansi, manajemen keuangan daerah dan perencanaan (baik dalam jangka pendek, jangka menengah maupun jangka panjang) merupakan suatu tuntutan yang sangat wajar untuk mendukung usaha otonomisasi. Dengan demikian warga masyarakat yang menikmati semua jasa suatu daerah dari kontribusi pendapatan di daerah. Munawir (1998) mendefi-nisikan Kontribusi adalah sumbangan yang diberikan oleh sektor tertentu dalam tatanan infrastruktur pembangunan daerah.

\section{Keuangan Daerah}

Penyelenggaraan,pemerinta han di daerah sebagai suatu organisasi perlu didukung oleh berbagai faktor sumber daya yang mampu menggerakkan jalannya roda pemerintahan dalam rangka mencapai tujuan, salah satu factor utama adalah faktor keuangan yang merupakan sumber daya bagi pembiayaan penyelenggaraan urusan rumah tangga daerah. Kebijakan keuangan daerah ditujukan pada peningkatan kemampuan daerah dalam membiayai urusan rumah tangganya sendiri, serta harus diprioritaskan pada penggalian dan mobilesasi sumber-sumber penerimaan di daerah.

Faktor keuangan daerah menjadi begitu penting karena tanpa adanya biaya yang cukup, pemerintah daerah tidak dapat melaksanakan fungsinya dengan efektif dan efisien tanpa biaya yang cukup untuk memberikan pelayanan dan pembangunan seperti dikemukan oleh Kaho (1997) dalam Isir (2003). Faktor keuangan menjadi salah satu indikator utama untuk mengukur tingkat kemampuan daerah dalam melaksanakan otonomi daerah. Jaya (1996) dalam Isir (2003) menjelaskan bahwa keuangan daerah adalah segala hak dan atau kekayaan daerah yang dapat dinilai dengan uang, demikian juga segala sesuatu yang dapat dijadikan milik daerah atau menjadi beban daerah berhubungan dengan hak tersebut (Isir, 2003). Keuangan daerah juga diartikan sebagai seluruh tatanan, perangkat, kelembagaan dan kebijaksanaan anggaran daerah.

\section{Pajak Daerah, Retribusi Daerah dan Laba Usaha Badan Usaha Da- erah.}

Meskipun tiada jasa timbal balik yang bersifat kontraprestasi langsung yang harus diberikan Pemerintah kepada pembayar pajak atau rakyat, namun menggarisbawahi bahwa Pemerintah tetap wajib memberikan jasa imbal yang bersifat tidak langsung kepada rakyat (pembayar pajak) dalam wujud pembangunan yang kegunaannya bukan secara individual, namun ditujukan kepada kepentingan umum atau masyarakat (Meliala,1991).

Pada dasarnya tidak terdapat perbedaan konsep antara pajak secara umum dengan Pajak Daerah.Terlihat berbeda menurut (Mardiasmo,2004), aparat pemungut, dasar pemungutan, dan penggunaan pajak yang dipungut oleh Pemerintah daerah dengan pengaturan dari daerah sendiri. Oleh karena itu dapat dikatakan bahwa unsur-unsur yang terdapat dalam pajak juga dapat dite- 
mukan pada pajak daerah (Davey,1988).

$$
\text { Pajak (termasuk pajak }
$$

daerah) pada dasarnya mempunyai fungsi yang diperkenalkan sebagai fungsi anggaran (budgetair) dan fungsi mengatur (regulation). Fungsi budgetair pajak mengemuka ketika pajak menjadi sumber pendanaan bagi Pemerintah untuk membiayai pengeluarannya baik pengeluaran rutin maupun pembangunan. Sementara, fungsi mengatur akan menonjol ketika Pemerintah menggunakan pajak untuk melaksanakan atau mengatur kebijakan di bidang sosial ekonomi untuk mencapai tujuan tertentu, misalnya ketika pajak yang tinggi dikenakan terhadap barang-barang mewah untuk mengurangi pola hidup konsumtif, atau pengenaan pajak ekspor nol persen untuk mendorong ekspor produk lokal ke pasar global (Mardiasmo,2004).

Untuk menilai kelayakan pajak daerah, lima alat tolok ukur, yang terdiri dari yield, equity, economic eficiency, ability to implement, dan suitability to local revenue source. Hasil (yield) terkait dengan memadai atau tidaknya suatu pajak dihubungkan dengan layanan publik yang dibiayainya, stabilitas dan mudah tidaknya memperkirakan besar hasil tersebut, elastisitas hasil pajak antara lain terhadap inflasi dan pertumbuhan penduduk, serta perbandingan hasil pajak dengan biaya pemungutannya. Keadilan (equity) merujuk kepada dasar pajak dan kewajiban membayar yang harus berorientasi pada asas keadilan dan ketidaksewenang - wenangan (Devas, et all, 1989).

Agar pemungutan pajak tidak menimbulkan hambatan atau perlawanan, maka pemungutan pajak menurut Wagner yang dikutip (Soetrisno,1982) harus memenuhi syarat (a) Keadilan, adil dalam hal perla- kuan yang merata dan bersifat umum disesuaikan dengan kemampuan masing-masing, serta adil dalam hal memberikan kesempatan kepada wajib pajak untuk mengajukan keberatan, penundaan pembayaran, dan banding; (b) Yuridis, berarti memberikan jaminan hukum baik bagi daerah maupun warganya; (c) Ekonomis, pemungutan pajak tidak boleh mengganggu kelancaran kegiatan produksi sehingga tidak menimbulkan kelesuan ekonomi; (d) Finansial, biaya pemungutan pajak harus lebih rendah dari hasil pemungutannya, dan (e) Sederhana, sistem pemungutan pajak harus memudahkan dan mendorong masyarakat memenuhi kewajiban perpajakannya (Mardiasmo, 2004).

\section{PAD Dalam Pendanaan Pembangu- nan Daerah}

Apabila Pemerintah daerah melaksanakan fungsinya secara efektif, dan diberikan kebebasan dalam pengambilan keputusan penyediaan pelayanan di sektor publik, maka mereka harus didukung sumber-sumber keuangan yang memadai baik yang berasal dari Pendapatan Asli Daerah (PAD) termasuk surcharge of taxes, Bagi Hasil Pajak dan Bukan Pajak, Pinjaman, maupun Subsidi/Bantuan dari Pemerintah Pusat. Pelaksanaan desentralisasi fiskal tersebut akan berjalan dengan baik apabila terdapat pengawasan dan enforcement yang dilakukan oleh Pemerintah Pusat yang kapabel, dan terdapat keseimbangan antara akuntabilitas dan kewenangan dalam melakukan pungutan pajak dan retribusi daerah. Di Indonesia, daerah memperoleh kewenangan untuk memanfaatkan sumber keuangan sendiri dan didukung dengan perimbangan keuangan antara pusat dan daerah, kebijaksanaan perimbangan keuangan antara pusat dan daerah dilakukan dengan mengikuti pembagian kewe- 
nangan atau money follows function. Hal ini berarti bahwa hubungan keuangan antara pusat dan daerah perlu diberikan pengaturan sedemikian rupa, sehingga kebutuhan pengeluaran yang akan menjadi tanggung jawab daerah dapat dibiayai dari sumber sumber penerimaan yang ada (Sidik,2002).

Dengan kewenangan yang dimiliki pemerintah daerah, sumbersumber pendapatan yang ada di daerah harus mampu digali oleh pemerintah daerah (Booth, 1993), Kemandirian fiskal daerah tidak akan terjadi apabila pusat menguasai sebagian besar sumber dana, sebaliknya yang akan terjadi adalah ketergantungan yang semakin besar. Oleh karena itu sesuai dengan kewenangannya daerah menggali sumber-sumber pendapatan daerah melalui intensifikasi dan ekstensifikasi pemungutan yang mana intensifikasi dan ekstensifikasi pemungutan merupakan alat yang dapat diharapkan untuk meningkatkan PAD (Kamaluddin, 1984).

Selain menerima dana perimbangan (DAU dan DAK) daerah juga dapat melakukan pinjaman untuk membiayai pembangunan. Pinjaman daerah merupakan semua jenis transaksi yang mengakibatkan daerah menerima dari pihak lain sejumlah uang atau manfaat bernilai uang sehingga daerah tersebut dibebani kewajiban untuk membayar kembali, tidak termasuk kredit jangka pendek yang lazim dalam perdagangan. Menurut pinjaman daerah digunakan untuk (a) menutupi defisit kas jangka pendek; (b) membiayai kekurangan dana anggaran tahunan berupa biaya rutin dan beban utama; (c) membeli pabrik dan peralatan dalam unsur jangka menengah; (d) membiayai investasi yang diharapkan dapat menghasilkan penerimaan daeran (cost recovery); dan (e) membiayai modal jangka panjang (Davey, 1988).

Untuk menghindari kemungkinan penurunan kemampuan Daerah dalam membiayai beban pengeluaran yang sudah menjadi tanggung jawabnya, maka perhitungan DAU disamping menggunakan formula fiscal gap juga menggunakan faktor penyeimbang (sesuai PP Nomor 104 tentang Dana Perimbangan sebagaimana telah direvisi dengan PP Nomor 84 Tahun 2001). Dengan adanya faktor penyeimbang, alokasi DAU kepada Daerah ditentukan dengan perhitungan formula fiscal gap dan faktor penyeimbang. Selain DAU terdapat pula Dana Alokasi Khusus (DAK), yaitu dana yang berasal dari APBN, yang dialokasikan kepada Daerah untuk membantu membiayai kebutuhan khusus. Pengalokasian DAK ditentukan dengan memperhatikan tersedianya dana dalam APBN. Yang dimaksud dengan kebutuhan khusus adalah (i) kebutuhan yang tidak dapat diperkirakan dengan menggunakan rumus alokasi umum, dalam pengertian kebutuhan yang tidak sama dengan kebutuhan Daerah lain, baik yang bersifat fisik maupun non fisik, misalnya: kebutuhan di kawasan transmigrasi, kebutuhan beberapa jenis investasi/ prasarana baru, pembangunan jalan di kawasan terpencil, saluran irigasi primer, dan pemberdayaan suku terasing; dan (ii) kebutuhan yang merupakan komitmen atau prioritas nasional (Yani,2002).

Menganjurkan Pemerintah daerah dalam memilih sumber dan metode pinjaman daerah didasarkan pada tujuan dan kepentingan pinjaman. Pinjaman daerah dapat bersumber dari Pemerintah yang lebih tinggi atau pemerintah pusat, Badan Internasional, dan Bank Sentral, sedangkan pinjaman jangka pendek dapat diberikan oleh Bank Umum. Pinjaman dapat pula berupa pinjaman tetap atau 
hipotek dan pinjaman internal yang biasanya berasal dari cadangan penerimaan negara. Aspek lain yang berkaitan dengan pinjaman daerah adalah kemampuan daerah mengembalikan pinjaman, manfaat proyek yang dibiayai oleh pinjaman, dan hal-hal yang berkaitan dengan teknis proyek (Davey, 1988).

Di Indonesia, menurut penelitian Bappenas (2005) berjudul Peta Kemampuan Keuangan Provinsi Dalam Era Otonomi Daerah, ditemukan bahwa meskipun belum optimal, ternyata terdapat dinamika dan upaya daerah untuk meningkatkan kemampuan pendanaan pembangunannya melalui peningkatan kemampuan keuangan dan mendorong potensi ekonomi lokal berdasarkan potensi yang dimilikinya. Beberapa upaya tersebut justru menimbulkan ekses berupa kebijakan demi peningkatan kemampuan sumber keuangan lokal yang bersifat kontra produktif terhadap peningkatan investasi. Pengalaman daerah dalam meningkatkan sumber keuangan lokal atau PAD di antaranya adalah (i) intensifikasi dan ekstensifikasi pajak, (b) negosiasi ulang kerjasama dengan pihak ketiga, (c) mengakomodasikan penerimaan dinas eks kantor wilayah, dan (4) mengoptimalisasikan sumbangan pihak ketiga. Sementara teladan yang terkait dengan peningkatan investasi antara lain (a) dukungan infrastruktur dasar dan penunjang, politik, dan hankam, (b) revitalisasi institusi di bidang investasi, (c) kerjasama regional, (d) kemudahan informasi, dan (e) pemberian fasilitas insentif.

Dalam konsep otonomi daerah dijelaskan bahwa suatu daerah disebut sebagai daerah otonom, jika daerah tersebut memiliki sumber-sumber keuangan. Hal tersebut diperlukan agar daerah dapat mengurus rumah tangganya sendiri dengan sebaik-baik- nya. Salah satu sumber keuangan daerah adalah berasal dari Pendapatan Asli Daerah (PAD). Pendapatan Asli Daerah (PAD) yang potensinya berada di daerah dan dikelola oleh pemerintah daerah yang bersangkutan. PAD ini merupakan salah satu sumber pendapatan yang cukup diandalkan oleh pemerintah daerah Kabupaten/kota, karena dana ini murni didapatkan sendiri dan dapat digunakan sepenuhnya untuk dimanfaatkan sesuai prioritas daerah dalam menjalankan penyelenggaraan pemerintahan dan pembangunan daerah (Soeratno,2002).

Selanjutnya Pendapatan Asli Daerah (PAD) pada dasarnya pendapatan yang berasal dari sumber-sumber keuangan daerah, seperti pajak daerah, retribusi daerah, bagian laba BUMD, penerimaan dinas-dinas dan penerimaan lain. Pendapatan Asli Daerah sebagai sumber penerimaan murni daerah yang selalu diupayakan agar terus meningkat. Dalam perspektif otonomi daerah, Pendapatan Asli Daerah (PAD) menjadi sumber keuangan yang paling utama selain jenisjenis penerimaan daerah lainnya. Besar kecilnya Pendapatan Asli Daerah (PAD) akan sangat menentukan kemampuan daerah untuk membiayai segala urusan rumah tangganya serta kegiatan-kegiatan pengembangan yang direncanakan setiap tahun.

Pendapatan Asli Daerah sebagai salah satu sumber penerimaan yang harus selalu dan terus menerus dipacu pertumbuhannya. Jumlah dan kenaikan kontribusi Pendapatan Asli Daerah (PAD) pemerintah kabupaten/kota akan dapat berperan dalam rencana peningkatan kemandirian pemerintah daerah untuk tidak selalu tergantung pada pemerintah pusat dan pemerintah provinsi. Seperti yang ditegaskan bahwa penerimaan daerah yang terpenting banyak tergantung pada tingkat pendapatan dan pereko- 
nomian setempat yang langsung dipengaruhi oleh tingkat perkembangan ekonomi nasional. Usaha peningkatan Pendapatan Asli Daerah (PAD) yang tanpa memperhatikan efeknya terhadap kegiatan ekonomi dan potensi yang ada, akan menimbulkan gangguan kelancaran ekonomi dan perdagangan, bahkan mungkin menghambat perkembangan sektor-sektor ekonomi tertentu (Kristiadi,1988).

Kemampuan daerah dalam memobilisasi Pendapatan Asli Daerah (PAD) dapat diukur melalui : (1) peranan Pendapatan Asli Daerah (PAD) dalam membiayai pengeluaran rutin dan atau (2) perbandingan antara Pendapatan Asli Daerah (PAD) dengan Produk Domestik Regional Bruto (PDRB) non migas masing-masing daerah. Besarnya perubahan Pendapatan Asli Daerah (PAD) terhadap pengeluaran rutin daerah (dalam persen) sering disebut Indeks Kemampuan Rutin (Djojosubroto,1992)

Pasal 4 Undang-undang Nomor 33 tahun 2004 menyatakan bahwa sumber Pendapatan Asli Daerah (PAD) terdiri dari beberapa sumber antara lain dari hasil pajak daerah melalui pembayaran perorangan kepada pemerintah yang sifatnya paksaan ataupun iuran masyarakat berdasarkan Undang-Undang yang berlaku, guna membiayai pengeluaran pemerintah, yang prestasi kembalinya tidak dapat ditunjuk secara langsung tetapi pelaksanaannya dapat dipaksakan bisa juga peraturan pajak yang ditetapkan oleh daerah untuk membiayai rumah tangganya sebagai hukum publik dan lapangan pajak adalah lapangan pajak yang belum digunakan dan diusahakan oleh negara. Selain pajak retribusi daerah yang mana pungutan daerah yang dilakukan atas pembayaran pemakaian atau karena memperoleh jasa pekerjaan, usaha atau milik daerah bagi yang berkepen- tingan atau karena jasa yang dibebankan oleh daerah dapat menjadi potensi penerimaan daerah yang cukup potensial (Soetrisno, 1984).

Sumber-sumber Pendapatan Asli Daerah (PAD), tidak dapat dipisahkan dari pendapatan daerah secara keseluruhan. Menurut Undang-Undang Nomor 32 tahun 2004 tentang pemerintahan daerah dan UndangUndang Nomor 33 Tahun 2004 tentang perimbangan keuangan antara pusat dan daerah, maka sumber pendapatan daerah terdiri atas Pendapatan Asli Daerah, terdiri dari hasil pajak daerah, hasil retribusi daerah, hasil Perusahaan Milik Daerah (BUMD), lain-lain Pendapatan Asli Daerah yang sah, dana Perimbangan, pinjaman daerah, lain-lain pendapatan daerah yang sah (Soetrisno, 1984).

Penerimaan daerah merupakan sumber pembiayaan pembangunan daerah merupakan sumber pembiayaan pembangunan daerah dan penyelenggara pemerintah daerah. Sumber pembiayaan pemerintah tersebut terdiri dari tiga komponen besar yaitu Pendapatan Asli Daerah, yang meliputi hasil pajak daerah, hasil retribusi daerah, hasil Perusahaan daerah (BUMD), lain-lain hasil usaha daerah yang sah, pendapatan yang berasal dari pusat, meliputi sumbangan dari pemerintah, sumbangan lain yang diatur dengan peraturan perundangundangan dan lain-lain pendapatan daerah yang sah. Sumber-sumber pembiayaan penyelenggaraan pemerintahan daerah bersumber dari Pendapatan Asli Daerah (PAD), Dana Perimbangan, Pinjaman daerah dan sumber-sumber penerimaan lainnya Macam-macam sumber pembiayaan pembangunan pemerintahan daerah yang diperoleh dari penerimaan daerah bisa juga dari sisa lebih perhitungan anggaran tahun lalu, pendapatan Asli Daerah (PAD) yang terdiri 
dari pos pajak daerah, pos retribusi daerah, pos laba Badan Usaha Milik Daerah (BUMD), pos penerimaan dari dinas-dinas, pos penerimaan lain-lain seperti bagian hasil pajak dan bukan pajak, bagian dari sumbangan dan bantuan, penerimaan pembangunan yakni dari pinjaman pemerintah dan pinjaman untuk Badan Usaha Milik Daerah (BUMD) (Soeratno,2002).

$$
\text { Selanjutnya, kedua }
$$
pandangan di atas sama dengan pandangan menurut pasal 79 dari Undang-undang Nomor 32 Tahun 2004 dan pasal 3 dari Undang-undang Nomor 33 Tahun 2004, dimana disebutkan bahwa penerimaan daerah terdiri dari penerimaan asli daerah, yang umumnya berasal dari pajak dan retribusi daerah, dana perimbangan, yang berasal dari Dana Alokasi Umum (DAU), Dana Alokasi Khusus (DAK) dan Dana Bagi Hasil (DBH) termasuk sumber daya alam, pinjaman daerah dan lain-lain penerimaan yang sah (Yani,2002)

Gambaran mengenai keuangan daerah khususnya penerimaan daerah tercermin dalam Anggaran Pendapatan dan Belanja Daerah (APBD) di setiap tahun anggaran, tidak terkecuali pada daerah Kabupaten/kota. Sumber-sumber penerimaan daerah Kabupaten/kota dalam Anggaran Pendapatan dan Belanja Daerah (APBD) dirinci menjadi Pendapatan Asli Daerah (PAD) yang diperoleh dari pajak daerah, retribusi daerah, bagian laba BUMD dan lain-lain pendapatan yang sah, bagian hasil pajak dan bukan pajak dari pemerintah pusat dan provinsi, sumbangan dari pemerintah pusat dan provinsi, penerimaan pembangunan (pinjaman daerah), sisa anggaran tahun sebelumnya. Pemerintah daerah memiliki berbagai sumber Pendapatan Asli Daerah sebagai sumber penerimaan. Salah satunya berupa pajak dae- rah yang merupakan imbalan dari pelayanan yang diberikan. Sebagian imbalan tersebut digolongkan dalam retribusi dan ada pula dicatat dalam penerimaan dinas-dinas daerah, kebijakan memungut bayaran untuk barang dan layanan yang disediakan pemerintah berpangkal dari efisiensi ekonomi (Devas, 1989).

UU No.32 tahun 2004 dan UU No.33 tahun 2004 memberikan implikasi yang sangat mendasar yang mengarah pada perlu dilakukannya reformasi sektor publik dan dipakainya paradigma baru dalam pengelolaan keuangan daerah. Refor-masi sektor publik tersebut harus dii-kuti dengan reformasi kelembagaan menyangkut pembenahan seluruh alat-alat negara di daerah hendaknya tidak lagi dijadikan sebagai alat pemerintah pusat semata-mata, namun lebih diorientasikan pada pelaksanaan lembaga tersebut secara ekonomis, efisien dan efektif, transparan, memiliki akuntabilitas dan kepekaan yang tinggi terhadap aspirasi masyarakat di daerah. Kunci reformasi kelembagaan adalah sebagai stakeholder, pemerintah daerah sebagai eksekutif dan DPRD sebagai Shareholder dengan memberikan tanggung jawab, wewenang dan kesempatan yang lebih luas untuk menentukan kebijakan daerahnya sendiri.

Sehubungan dengan berbagai kegiatan pemerintah daerah yang dibiayai melalui kemampuan keua-ngan daerah, maka posisi keuangan daerah memegang peran yang sangat penting dalam mendukung penyelenggaraan pemerintah di daerah. Keuangan daerah dapat dijadikan sebagai cerminan tujuan jangka panjang, jangka menengah dan jangka pendek dari setiap organisasi yang akan melaksanakan program yang diusulkan berkaitan dengan kebutuhan anggaran atau pembelanjaan pada sisi manajemen keuangan 
daerah secara garis besar dapat dibagi menjadi dua bagian, yaitu manajemen penerimaan daerah dan manajemen pengeluaran daerah. Evaluasi terhadap pengelolaan keuangan daerah dan pembiayaan pembangunan daerah mempunyai implikasi yang sangat luas. Kedua komponen tersebut akan sangat menentukan kedudukan suatu pemerintah daerah dalam rangka melaksanakan otonomi daerah (Mardiasmo, 2002).

Pemerintah

daerah

berdasarkan Undang-undang Nomor 32 Tahun 2004 berhak untuk mempunyai organisasi sendiri, mengangkat pegawai dan menggali sumber-sumber pendapatan sendiri. Pemberian kewenangan kepada pemerintah daerah bukan hanya proses administrasi, tetapi juga proses pembangunan yang dilaksanakan di daerah. Secara ringkas pemberian wewenang kepada pemerintah daerah perlu memperhatikan unsur-unsur penting berikut ini : (1) kemampuan kelembagaan, (2) Ketersediaan sumber daya manusia yang memadai, khususnya aparatur pemerintah daerah dan (3) potensi ekonomi daerah untuk menggali sumber pendapatannya (Sumodiningrat, 1997).

\section{Peranan pemerintah (sektor publik) dalam perekonomian daerah}

Pembangunan ekonomi

daerah adalah suatu proses dimana pemerintah daerah dan kelompokkelompok masyarakat mengelola sumber daya yang ada dan membentuk suatu pola kemitraan antara pemerintah daerah dengan swasta untuk menciptakan suatau lapangan lapangan kerja baru dan mendorong perkembangan kegiatan ekonomi dalam wilayah tersebut. Pembangunan daerah pada hakekatnya adalah merupakan bagian integral dari pembangunan nasional, maka dalam pelaksanannya kebijaksanaan pembangunan daerah tidak akan terlepas dari pembangunan nasional.

Upaya untuk memacu pertumbuhan ekonomi di daerah telah dilaksanakan dalam bentuk pemberian subsidi dan bantuan serta insentif pajak bagi daerah-daerah terbelakang. Sebagaimana kebijakan dan upaya yang dilakukan oleh pemerintah pusat dalam kegiatan pembangunan ekonomi baik upaya yang sudah dicapai maupun yang masih dalam proses, maka peran yang dilakukan pemerintah Kabupaten Badung dalam perekonomian adalah memberikan stimulan dan lebih mendorong tumbuhnya perekonomian rakyat.

Pengeluaran pemerintah mencerminkan kebijakan pemerintah. Apabila pemerintah telah menetapkan suatu kebijakan untuk membeli barang dan jasa, pengeluaran pemerintah mencerminkan biaya yang harus dikeluarkan oleh pemerintah untuk melaksanakan kebijakan tersebut.

Dalam model pembangunan tentang perkembangan pengeluaran pemerintah yang dikembangkan oleh Rostow dan Musgrave dalam Mangkoesoebroto (1999) bahwa pada tahap awal perkembangan ekonomi, persentase investasi pemerintah terhadap total investasi sangat besar. Hal ini disebabkan oleh karena pada tahap ini pemerintah harus menyediakan prasarana. Peranan pemerintah tetap besar pada tahap menengah oleh karena peranan swasta yang semakin besar ini banyak menimbulkan kegagalan pasar.

\section{Teori Pertumbuhan Ekonomi.}

Pengertian pertumbuhan ekonomi sudah banyak dirumuskan dengan sudut pandang yang berbeda oleh para ekonom. Boediono (1999) mengemukakan bahwa pertumbuhan ekonomi merupakan proses kenaikan output perkapita dalam jangka panjang. Penekanan di sini adalah pada 
proses karena mengandung unsur perubahan dan indikator pertumbuhan ekonomi dilihat dalam kurun waktu yang cukup lama.

Teori pertumbuhan secara umum terbagi dalam dua kelompok pendekatan yaitu pendekatan klasik yang dipelopori oleh Adam Smith, David Ricardo dan Arthur Lewis dan modern yang dianut oleh Keynes (Harrod-Domar), Neo Klasik (SolowSwan). Menurut teori pertumbuhan Adam Smith dalam Boediono (1999), proses pertumbuhan ekonomi dalam jangka panjang menyangkut dua aspek utama yaitu pertumbuhan output total yang berupa sumber daya alam, sumber daya manusia dan stok modal.

\section{Pendapatan daerah dan pertumbuhan ekonomi}

Pendapatan daerah terdiri dari sisa lebih perhitungan tahun yang lalu, pendapatan asli daerah, bagi hasil pajak dan bukan pajak, sumbangan dan bantuan serta pinjaman. Pendapatan daerah yang terbesar dikumpulkan melalui penerimaan pajak akan mengurangi kemampuan daya beli masyarakat yang mengakibatkan rendahnya pertumbuhan ekonomi.

\section{Investasi pemerintah dan pertumbuhan ekonomi}

Investasi pemerintah daerah dalam hal ini dinyatakan dalam belanja pembangunan yang dapat berpengaruh terhadap pertumbuhan ekonomi. Dana tersebut digunakan untuk memberdayakan berbagai sumber ekonomi untuk mendorong pemerataan dan peningkatan penda-patan perkapita. Dana pembangunan juga merupakan salah satu input produksi yang dapat menghasilkan output.

Pengeluaran konsumsi pemerintah dan pertumbuhan ekonomi
Pengeluaran konsumsi pemerintah daerah diukur dengan pengeluaran rutin. Pengeluaran rutin ini mempunyai peranan dan fungsi cukup besar dalam mendukung pencapaian sasaran pembangunan sekalipun pengeluaran tersebut tidak secara langsung berkaitan dengan pembentukan modal untuk tujuan peningkatan produksi, melainkan menunjang kegiatan pemerintahan serta peningkatan jangkauan dan mutu pelayanan.

\section{Angkatan kerja dan pertumbuhan ekonomi}

Sumber daya manusia merupakan salah satu faktor dinamika dalam perkembangan ekonomi jangka panjang bersamaan dengan ilmu pengetahuan, teknologi sumber daya alam dan kapasitas produksi. Pertumbuhan penduduk dan tenaga kerja dianggap sebagai faktor positif dalam merangsang pertum-buhan ekonomi. Jumlah tenaga kerja yang besar dapat berarti menambah jumlah tenaga produktif. Dengan meningkatnya produktivitas tenaga kerja diharapkan akan meningkatkan produksi, yang berarti akan meningkatkan pula PDRB.

\section{Investasi swasta dan pertumbuhan ekonomi}

Peranan sektor swasta dalam kegiatan perekonomian daerah terutama adalah untuk menanamkan modalnya baik didaerah maupun tingkat regional, sehingga dapat memacu pertumbuhan ekonomi. Perkembangan investasi swasta sangat tergantung dari fasilitas dan kemudahan yang diberikan oleh pemerintah, berupa sarana dan prasarana yang merangsang guna menarik investor asing maupun dalam negeri.

Setiap daerah dituntut dapat berperan aktif dalam mengelola dan 
mengembangkan sektor publik dalam upaya meningkatkan pertumbuhan ekonomi daerah dan kemandirian serta mampu bersaing dengan daerah lainnya. Pembelian oleh pemerintah dan swasta dapat dipandang sebagai pengeluaran agregat untuk output yang diproduksi selama periode tertentu. Pengeluaran yang dilakukan oleh Pemerintah dapat dibedakan yaitu pertama pembelian faktor-faktor produksi (input) dan pembelian produk (output), Kedua, untuk pengeluaran konsumsi pemerintah (belanja rutin) serta untuk investasi pemerintah (belanja pembangunan/barang-barang modal). Dalam sistem perekonomian pasar yang memberikan hak hidup dengan layak kepada unsur swasta, maka kebijakan ekonomi dapat dalam dilakukan dalam bentuk pemberian insentif, promosi dan bimbingan terhadap swasta.

\section{Royalti}

Berdasarkan Undang-undang Nomor 32 Tahun 2004 bahwa dalam rangka pembiayaan pelaksanaan desentralisasi, kepada daerah dialokasikan dana perimbangan yang terdiri dari bagian daerah dari penerimaan Bea Perolehan Hak Atas Tanah Bangunan (BPHTB), penerimaan Sumber Daya Alam (SDA), Dana Alokasi Umum (DAU) dan Dana Alokasi Khusus (DAK).

Bagi daerah yang mempunyai sumber daya alam yang banyak, maka secara logika potensi sumber keuangannya akan lebih besar dari daerah yang mempunyai sumber daya alam yang kecil. Berdasarkan Peraturan Pemerintah Nomor 55 tahun 2005 Tentang Dana Perimbangan bahwa penerimaan pertambangan umum sebagaimana dimaksud dalam pasal 14 huruf $\mathrm{c}$ terdiri atas (a) penerimaan iuran tetap (land rent) (b) penerimaan iuran eksplorasi dan iuran eksploitasi (royalti).

Dana Bagi Hasil (DBH) dari penerimaan Negara iuran tetap yang menjadi bagian daerah di bagi dengan rincian :

1) $16 \%$ (enam belas persen) untuk propinsi yang bersangkutan.

2) $64 \%$ (enam puluh empat persen) untuk Kabupaten/kota penghasil.

Dana Bagi Hasil (DBH) dari penerimaan Negara iuran eksplorasi dan iuran eksploitasi yang menjadi bagian daerah dibagikan dengan rincian :

a. $16 \%$ (enam belas persen) untuk provinsi yang bersangkutan.

b. $32 \%$ (tiga puluh dua persen) untuk kabupaten/kota penghasil.

c. $32 \%$ (tiga puluh dua persen) untuk Kabupaten/kota lainnya dalam provinsi yang bersangkutan.

\section{Penelitian Terdahulu}

1) Malanuang (2002) menyatakan bahwa sejak mulai memasuki tahapan operasi dari sisi social dan ekonomi PT NNT memunculkan beberapa permasalahan. Pertama, kurang memberikan kontribusi terhadap upaya peningkatan kesejahteraan masyarakat lingkar tambang. Masyarakat justru kehilangan berbagai aksesabilitasnya antara lain akses terhadap sumber daya laut, sumber daya hutan, lahan produktif, menyempitnya daerah pengembalaan ternak, hilangnya fungsi sungai. Kedua, tidak mempunyai keterkaitan yang signifikan untuk menarik dan mendorong sektor ekonomi di Provinsi Nusa Tenggara Barat. Ketiga, PT NNT menyebabkan 
kebocoran wilayah yang sangat besar karena tidak menggunakan input domestik. Ketiga, munculnya berbagai permasalahan sosial budaya dalam masyarakat lingkar tambang. Keempat, program pengembangan masyarakat PT. NNT belum diterima baik oleh masyarakat karena program tersebut belum dilaksanakan secara baik, terprogram dan secara tepat, serta belum dapat dirasakan secara merata oleh masyarakat secara keseluruhan. Kelima, terjadinya ketidakadilan dalam pengelolaan sumber daya mineral oleh PT. NNT yang cenderung merugikan masyarakat dan daerah penghasil. Keenam, secara ekonomi, kebijakan pengembangan PT NNT di blok Dodo dan Rinti tidak layak. Usaha pertambangan terbuka (Open pit mining) di dalam hutan lindung yang dengan lahan pertanian masyarakat, dengan sungai dan laut akan cenderung berpotensi menyebabkan terjadinya kerusakan (degradasi) lingkungan dan penyusutan (deplesi) sumber daya alam karena pengambilan biji emas yang ada di bawah permukaan tanah dilakukan dengan membabat hutan dan penggalian tanah cukup dalam $(900 \mathrm{~m}$ di bawah permukaan laut) dan relatif luas dengan diameter lubang galian $2 \mathrm{~km}$ ) dan limbahnya pun langsung dibuang ke sungai dan ke laut. Jika keadaan ini dibiarkan berlangsung terus menerus dalam jangka waktu yang lama (30 tahun), maka tidak mustahil kehidupan di wilayah tersebut dan sekitarnya akan musnah menjadi daerah tak bertuan atau ghost city
2) Maya (2006), melakukan penelitian dengan judul kontribusi sektor pariwisata terhadap pendapatan asli daerah Kabupaten Pacitan tahun 19992005. Tujuan penelitian ini adalah untuk mengetahui sejauh mana perkembangan pendapatan sektor pariwisata di Kabupaten Pacitan, jika jumlah objek pariwisata, jumlah pengunjung, akomodasi, promosi dan publikasi dan untuk mengetahui kontribusi pendapatan sektor pariwisata terhadap Pendapatan Asli Daerah (PAD) serta untuk mengetahui usaha-usaha apa saja yang dapat dikembangkan disekitar objek wisata yang ada di Kabupaten Pacitan. Dalam penelitian ini peneliti menggunakan teknik analisa presentase untuk mengetahui perkembangan sektor pariwisata yang dilihat dari tingkat kunjungan wisatawannya dari tahun ke tahun. Dan yang kedua menggunakan teknik analisa kontribusi di mana teknik ini digunakan untuk mengetahui seberapa besar kontribusi sektor pariwisata terhadap Pendapatan Asli Daerah (PAD). Dan untuk usaha-usaha yang dapat dikembangkan di sektor objek wisata peneliti menggunakan deskriptif kualitatif. Hasil penelitian menggunakan analisa persentase dapat diketahui tingkat kunjungan wisatawan yang berkunjung di Kabupaten Pacitan tiap tahun mengalami naik turun, ini dikarenakan banyaknya pasilitas objek wisata yang rusak, dan dengan analisa kontribusi dapat diketahui perkembangan sektor pariwisata tiap tahunnya 22,1 persen. Berdasarkan hasil penelitian di atas 
peneliti dapat mengimplementasikan bahwa sebaiknya pemerintah daerah dapat menarik pihak swasta untuk menanamkan modalnya di sektor pariwisata agar dapat meningkatkan perkembangan sektor pariwisata itu sendiri, dan juga pemerintah dapat segera melaksanakan perencanaan dan penataan ulang kembali terhadap objek wisata yang rusak dan tidak terawatt dan memberikan kenyamanan bagi setiap pengunjung.

3) Ratrisasi,dkk (2002), melakukan penelitian dengan judul kontribusi objek wisata di kota Yogyakarta terhadap Pendapatan Asli Daerah (PAD). Tujuan penelitian ini adalah meneliti kontribusi objek wisata di Kota Yogyakarta terhadap Pendapatan Asli Daerah (PAD). Alat analisis yang digunakan adalah pedoman dari ESCAP (Economic and Social Comission for Asia and Pacific) mengenai panduan analisis input-output pada sektor pariwisata. Berdasarkan hasil temuan analisis yang telah dilakukan, diketahui bahwa kontribusi pajak dan retribusi pariwisata di kota Yogyakarta masih kecil yaitu rata-rata setiap tahunnya sebesar 15,2 persen dengan porsi pajak terbesar berasal dari pajak hotel dan restoran. Factor penghambat yang ditemui dalam meningkatkan kontribusi sektor pariwisata terhadap PAD ini ialah masih adanya beberapa objek wisata potensial yang belum memberikan kontribusi terhadap Pendapatan Asli Daerah (PAD) karena status kepemilikannya bukan oleh pemerintah daerah kota Yogyakarta. Temuan analisis ini selanjutnya digunakan untuk me- nyusun rekomendasi mengenai upaya peningkatan kontribusi dari pengembangan objek-objek wisata terhadap Pendapatan Asli Daerah (PAD) kota Yogyakarta.

\section{Kerangka Konseptual Penelitian}

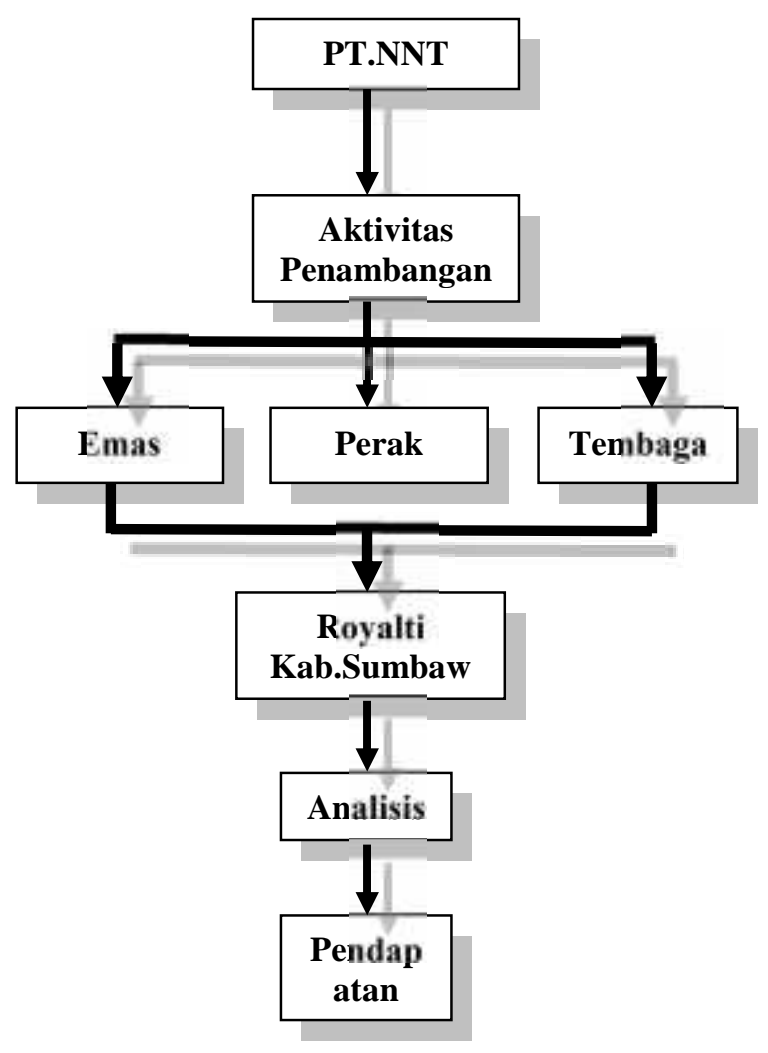

\section{Hipotesis}

Hipotesis adalah dugaan atau jawaban sementara yang masih membutuhkan pengujian untuk membuktikan kebenarannya. Hipotesis berguna untuk mengarahkan penelitian menjadi lebih fokus pada objek kajian sehingga penelitian tidak menghasilkan interpretasi yang luas. Adapun hipotesis penelitian ini adalah diduga royalti PT NNT memiliki kontribusi yang besar terhadap pendapatan daerah Kabupaten Sumbawa Barat tahun 2006-2012. 


\section{METODE PENELITIAN}

\section{Jenis Penelitian}

Penelitian ini menggunakan metode deskriptif yaitu suatu bentuk penelitian yang ditujukan untuk mendeskripsikan fenomena-fenomena yang ada, baik fenomena alamiah maupun fenomena buatan manusia. Fenomena itu bisa berupa bentuk, aktivitas, karakteristik, perubahan, hubungan, kesamaan, dan perbedaan antara fenomena yang satu dengan fenomena lainnya (Sukmadinata, 2006).

Penelitian deskriptif merupakan penelitian yang berusaha mendeskripsikan dan menginterpretasikan sesuatu, misalnya kondisi atau hubungan yang ada, pendapat yang berkembang, proses yang sedang berlangsung, akibat atau efek yang terjadi, atau tentang kecendrungan yang tengah berlangsung. Fenomena disajikan secara apa adanya, hasil penelitiannya diuraikan secara jelas tanpa manipulasi oleh karena itu penelitian ini tidak adanya suatu hipotesis tetapi adalah pertanyaan penelitian. Analisis deskriptif dapat menggunakan analisis distribusi frekuensi yaitu menyimpulkan berdasarkan hasil rata-rata. Hasil penelitian deskriptif sering digunakan, atau dilanjutkan dengan melakukan penelitian analitik. Jenis penelitian yang termasuk dalam kategori deskriptif adalah studi kasus dan penelitian survey

Penggunaan metode deskriptif pada penelitian ini didasarkan pada permasalahan yang dihadapi yaitu berusaha memberikan suatu gambaran mengenai kontribusi royalti PT NNT terhadap pendapatan daerah Kabpaten Sumbawa Barat dengan cara mengumpulkan, mengolah dan menganalisa data yang berkaitan dengan masalah tersebut untuk kemudian menarik kesimpulan terhadap masalah yang dihadapi dalam ruang lingkup penelitian ini.

Jenis penelitian ini adalah deiskriptif kuantitatif, yaitu penelitian yang bertujuan untuk memberikan gambaran faktual menggunakan angka-angka. Dalam penelitian ini peneliti mencoba untuk menggali kontribusi royalti PT NNT terhadap pendapatan daerah di Kabupaten Sumbawa Barat selama tahun 2006-2012.

\section{Jenis Data}

1) Jenis data yang digunakan dalam penelitian ini adalah data kuantitatif yaitu data-data berupa angka-angka data yang dimaksud adalah realisasi penerimaan royalti PT NNT dan pendapatan daerah Kabupaten Sumbawa Barat selama tahun 20062012.

2) Data kuantitatif adalah data yang menjelaskan hasil penelitian pada perhitungan-perhitungan matematis yang kemudian memberikan gambaran/suatu fenomena kasus yang diajukan dalam penelitian.

Jenis data yang digunakan dalam penelitian ini yaitu data kualitatif dan kuantitatif.

1) Data Kualitatif

Data kualitatif yaitu data yang berbentuk kata-kata, bukan dalam bentuk angka. Data kualitatif diperoleh melalui berbagai macam teknik pengumpulan data misalnya wawancara, analisis dokumen, diskusi terfokus, atau observasi yang telah dituangkan dalam catatan lapangan (transkrip). Bentuk lain data kualitatif adalah gambar yang diperoleh melalui pemotretan atau rekaman video.

2) Data Kuantitatif

Data kuantitatif adalah data dalam bentuk angka-angka yang 
pembahasannya, melalui penghitungan statistik berdasarkan jawaban kuesioner dari responden. Hasil penghitungan dari skor atau nilai tersebut kemudian dalam analisis statistik sederhana untuk melihat kontribusi royalti PT NNT terhadap pendapatan daerah Kabupaten Sumbawa Barat.

\section{Sumber Data}

Sumber data yang digunakan dalam penelitian ini adalah :

1) Data Primer, yaitu data yang diperoleh atau dikumpulkan oleh peneliti secara langsung dari sumber datanya. Data primer disebut juga sebagai data asli atau data baru yang memiliki sifat terbaru. Untuk mendapatkan data primer, peneliti harus mengumpulkannya secara langsung. Teknik yang dapat digunakan peneliti untuk mengumpulkan data primer antara lain observasi, wawancara, diskusi terfokus dan penyebaran kuesioner.

2) Data Sekunder, yaitu data yang diperoleh atau dikumpulkan peneliti dari berbagai sumber yang telah ada (peneliti sebagai tangan kedua). Data sekunder dapat diperoleh dari berbagai sumber seperti Biro Pusat Statistik (BPS), buku, laporan, jurnal, dan lain-lain.

\section{Metode Pengumpulan Data}

Pengumpulan data dalam penelitian dilakukan dengan metode dokumentasi yaitu metode pengumpulan data dengan cara menyalin atau mencatat dokumen resmi dari Dinas Pengelolaan Pendapatan Keungan dan Ases Daerah serta Badan Pusat Statistik Kabupaten Sumbawa Barat.
Untuk mengumpulkan data dari sampel penelitian, dilakukan dengan metode tertentu sesuai dengan tujuannya. Ada berbagai metode, antara lain; wawancara, observasi (pengamatan), wawancara, kuesioner atau angket dan dokumenter. Metode yang dipilih untuk setiap variabel tergantung pada berbagai faktor terutama jenis data dan ciri responden. Untuk data historis misalnya tidak bisa ditemukan dengan observasi tetapi dimungkinkan dengan dokumenter atau wawancara. Hal ini tergantung pada karakteristik data variabel, maka metode yang digunakan tidak selalu sama untuk setiap variabel.

\section{Klasifikasi Variabel Penelitian}

Variabel dalam penelitian adalah mandiri yaitu variabel yang berdiri sendiri. Variabel mandiri dalam penelitian adalah kontribusi royalti PT. NNT terhadap pendapatan daerah Kabupaten Sumbawa Barat. Dalam menghindari terjadinya kesalahan dalam pengumpulan data dan untuk mempermudah penelitian ini agar data yang dihasilkan sesuai dengan variabel, maka dapat diketahui identifikasi dan klasifikasi variabel.

\section{Definisi Operasional Variabel}

Adapun definisi operasional variabel dalam penelitian ini adalah sebagai berikut :

1) Royalti PT. NNT adalah realisasi penerimaan royalti PT. NNT Kabupaten Sumbawa Barat selama tahun 2006-2012 (dalam satuan rupiah)

2) Pendapatan daerah adalah realisasi penerimaan daerah yang berasal Pendapatan Asli Daerah (PAD), dana perimbangan dan pendapatan daerah ain yang sah di Kabupaten Sumbawa Barat 
tahun 2006-2012 (dalam satuan rupiah).

\section{Tehnik Analisis Data}

Tehnik pengumpulan data yang digunakan dalam penelitian ini adalah Kuantitatif. Analisis data kuantitatif adalah pengolahan data dengan kaidah-kaidah matematik terhadap data angka atau numerik. Angka dapat merupakan representasi dari suatu kuantitas maupun angka sebagai hasil konversi dari suatu kualitas, yakni data kualitatif yang dikuantifikasikan (Sugiyono, 2007).

Adapun tehnik analisa data yang digunakan dalam penelitian ini adalah analisis kontribusi statistik sederhana dalam bentuk persentase yang diberikan oleh royalti PT NNT terhadap pendapatan daerah Kabupaten Sumbawa Barat setiap tahunnya. Analisis ini digunakan untuk menggambarkan besarnya kontribusi variabel royalti terhadap pendapatan daerah. Adapun prosedur analisisnya adalah sebagai berikut :

Untuk mengetahui kontribusi royalti PT NNT terhadap pendapatan daerah Kabupaten Sumbawa Barat, dalam penelitian ini dilakukan dengan rumus (Syafruddin,2002)

$$
\begin{array}{c|c|}
\hline & P n=\frac{Q X n}{Q Y n} \times 100 \% \\
& \text { Keterangan: } \\
\mathrm{P} \quad \begin{array}{l}
\text { Kontribusi royalti PT Newmont } \\
\text { Nusa Tenggara (NNT) }
\end{array} \\
\mathrm{QX \quad} \quad \begin{array}{l}
\text { Realisasis penerimaan royalti } \\
\text { PT Newmont Nusa Tenggara } \\
\text { (NNT) }
\end{array} \\
\mathrm{QY \quad} \quad \begin{array}{l}
\text { Realisasi penerimaan daerah } \\
\text { Kabupaten Sumbawa Barat }
\end{array} \\
\mathrm{n} \quad \begin{array}{l}
\text { Tahun tertentu dari tahun } 2006 \\
\text { sampai tahun 2012 }
\end{array}
\end{array}
$$

Apabila kontribusi royalti PT Newmont Nusa Tenggara (NNT) terhadap pendapatan daerah semakin tinggi setiap tahun, maka akan semakin baik bagi pendapatan daerah Kabupaten Sumbawa Barat karena akan mendorong peningkatan pendapatan daerah dari sektor lainnya.

\section{ANALISIS DATA DAN PEMBAHASAN}

\section{Keadaan Geografis Lokasi}

Kabupaten Sumbawa Barat yang terbentuk berdasarkan UU Nomor 30 Tahun 2003 tertanggal 20 November 2003 merupakan kabupaten pemekaran dari Kabupaten Sumbawa Barat Propinsi Nusa Tenggara Barat (NTB) dengan luas 1.849,02 $\mathrm{km}^{2}$ dengan 8 (delapan) kecamatan. Kecamatan Taliwang merupakan salah satu kecamatan yang ada dan sekaligus merupakan ibu kota dari Kabupaten Sumbawa Barat sejak ditetapkan sebagai kabupaten pemekaran tahun 2003 yang memiliki luas wilayah sebesar 375,93 $\mathrm{km}^{2}$. Berikut peta Kabupaten Sumbawa Barat sebagai berikut :

Kabupaten Sumbawa Barat merupakan hasil pemekaran dari Kabupaten Sumbawa Barat, propinsi Nusa Tenggara Barat (NTB) berdasarkan UU Nomor 30 Tahun 2003. Secara administratif, Kabupaten Sumbawa Barat ini memiliki luas $1.849,02 \mathrm{Km}^{2}$, yang terdiri dari 8 kecamatan, yaitu (Kecamatan Sekongkang, Kecamatan Maluk, Kecamatan Jereweh, Kecamatan Taliwang, Kecamatan Brang Rea, Kecamatan Seteluk, dan Kecamatan Poto Tano). Keunikan dari Kabupaten Sumbawa Barat adalah bahwa Kabupaten ini kaya sumber daya alam tetapi miskin infrastruktur. Miskinnya infrastruktur jalan yang menghubungkan sentrasentra kegiatan industri meskipun Kabupaten Sumbawa Barat memiliki sumber daya alam yang melimpah. 
Secara geografis Kabupaten Sumbawa Barat terletak antara $11^{0}, 34^{0}$ Bujur barat dan $117^{0} .38^{\prime \prime}$ bujur timur serta diantara $3^{0} .19^{\prime \prime}$ lintang selatan. Kabupaten Sumbawa Barat beriklim tropis mempunyai musim yang hampir sama dengan wilayah Nusa Tenggara Barat pada umumnya, yaitu musim penghujan dan musim kemarau. Musim kemarau biasanya terjadi pada bulan Mei sampai dengan Oktober sedangkan musim penghujan terjadi pada bulan Nopember sampai dengan bulan April.

Keadaan ini berlangsung setiap tahun diselingi dengan musim peralihan pada bulan-bulan tertentu. Namun, dalam tahun-tahun ini keadaan musim di Nusa Tenggara Barat kadang tidak menentu. Pada bulan-bulan seharusnya turun hujan dalam kenyataannya tidak turun hujan sama sekali begitu juga sebaliknya.

Bila dilihat dari segi topografinya, permukaan tanah di wilayah Kabupaten Sumbawa Barat tidak rata atau cenderung berbukit-bukit dengan ketinggian berkisar antara 0 hingga 1.730 meter d iatas permukaan laut, di mana sebagian besar di antaranya memiliki kemiringan tanah yang curam seluas $146.711 \mathrm{Ha}$ atau 79,35 persen dari luas wilayah Kabupaten Sumbawa Barat berkisar antara 10 sampai dengan 650 meter di atas permukaan laut.

Secara administratif Kabupaten Sumbawa Barat mempunyai luas daratan 184.902 yang didominasi oleh daerah yang sangat curam seluas 93.102 Ha dikarenakan banyak pegunungan kecil yang dibedah untuk menjadi badan jalan setelah itu diikuti oleh daerah yang curam sekitar 15- 40 $\%$ dari seluruh daerah di Kabupaten Sumbawa Barat sedangkan sisanya adalah daerah yang bergelombang dan sedikitnya lagi adalah daerah dataran. Kabupaten Sumbawa Barat terdiri dari
8 kecamatan dan 49 desa/kelurahan. Masing-masing kecamatan mempunyai luas yang berbeda-berbeda.

Daerah terluas dari 8 kecamatan yang ada di Kabupaten Sumbawa Barat adalah daerah Taliwang seluas $32.280 \mathrm{Ha}$ dengan jumlah desa dan kelurahan sebanyak 13 desa atau kelurahan. Sedangkan ukuran wilayah setelah Taliwang adalah Sekongkang padahal jika dilihat dari segi geografis paling jauh dari wilayah kota Taliwang. Selanjutnya adalah wilayah kecamatan Jereweh dengan luas wilayah seluas $26.019 \mathrm{Ha}$ yang diikuti oleh daerah kecamatan Seteluk dengan jumlah desa atau kelurahan seluas 7 desa, selanjutnya diikuti oleh kecamatan Poto Tano dan kecamatan Brang Ene merupakan kecamatan yang relatif kecil yang cukup dekat dengan pusat kota Taliwang dengan jumlah desa atau kelurahan sebanyak 9 kecamatan yang berada didalam dua kecamatan tersebut.

\section{Penduduk Kabupaten Sumbawa Barat}

Jumlah penduduk

Kabupaten Sumbawa Barat mengalami peningkatan yang cukup signifikan dari tahun ke tahun di mana pada tahun 2006 berjumlah 117.275 Jiwa meningkat 119.528 jiwa pada tahun 2012. jika dihitung laju pertumbuhan penduduk pada kurun waktu tersebut tercatat rata-rata 1,75 persen per tahun. Jumlah penduduk laki-laki masih mendominasi apabila dibandingkan dengan penduduk perempuan. Jumlah penduduk terbesar masih didominasi oleh penduduk ibu kota yang bertempat di kota Taliwang dengan jumlah penduduk sebesar 44.906 jiwa sedangkan penduduk yang lain yang mengikuti jumlah penduduk di ibu kota Taliwang adalah penduduk kecamatan Seteluk yang terletak sebelum memasuki ibu kota 
Taliwang, setelah itu diikuti oleh kecamatan Brang Ene, Maluk dan Poto Tano dengan jumlah penduduk berada pada kisaran 10 sampai 15 ribu penduduk. Semua komponen jumlah penduduk tersebut memberikan kejelasan bahwa penduduk Kabupaten Sumbawa Barat cukup besar dengan total penduduk sebanyak 119.528 jiwa.

\section{Struktur Ekonomi Kabupaten Sumbawa Barat}

Sebagai daerah baru terbentuk, perkembangan ekonomi daerah Kabupaten Sumbawa Barat dapat dikatakan cukup baik. Hal ini pertumbuhan ekonomi pada masingmasing lapangan usaha sektor primer seperti pertanian tumbuh rata-rata di atas 3 persen per tahun. Pertumbuhan sektor primer yang tinggi sangat penting, mengingat sektor ini yang paling banyak dimiliki oleh masyarakat.

Struktur ekonomi Kabupaten Sumbawa Barat masih didominasi oleh sektor perdagangan, restoran dan hotel. Sektor ini telah memberikan kontribusi nilai tambah sangat besar terhadap pembentukan Produk Domestik Regional Bruto (PDRB) Kabupaten Sumbawa Barat. Selain sektor pertambangan yang menjadi tiang perekonomian di Kabupaten Sumbawa Barat juga ada sektor-sektor lain sebagai penggerak perekonomian misalkan sektor perdagangan, restoran dan hotel sektor industri pengolahan juga diharapkan terus mengalami pertumbuhan yang meningkat sehingga akan memberikan kontribusi cukup besar berkisar antara 12-13 persen. Sektor lain yang juga akan memberikan kontribusi yang cukup besar terhadap struktur perekonomian Kabupaten Sumbawa Barat adalah sektor keuangan, persewaan, dan jasa peru- sahaan serta sektor pengangkutan dan komunikasi.

\section{Hasil Analisis dan Pembahasan}

Dalam mengaplikasikan metode kontribusi atau untuk mengukur besarnya kontribusi suatu sektor pada tahun tertentu dalam hal ini mengetahui kontribusi royalti yang diberikan kepada Kabupaten Sumbawa Barat oleh PT Newmont Nusa Tenggara (PT. NNT) terhadap peningkatan pendapatan daerah Kabupaten Sumbawa Barat.

Secara matematis formula untuk menghitung besarnya kontribusi royalti PT NNT terhadap pendapatan daerah Kabupaten Sumbawa Barat dituliskan sebagai berikut :

$$
P n=\frac{Q X n}{Q Y n} \times 100 \%
$$

Keterangan :

Pn = Kontribusi royalti PT Newmont Nusa Tenggara (NNT)

$\mathrm{QX}=$ Realisasis penerimaan royalti $\mathrm{PT}$ Newmont Nusa Tenggara (NNT)

$\mathrm{QY}=$ Realisasi penerimaan daerah Kabupaten Sumbawa Barat

$\mathrm{n}=$ Tahun tertentu dari tahun 2006 sampai tahun 2012

Berdasarkan formula tersebut di atas maka dapat dilakukan perhitungan kontribusi royalti PT NNT terhadap pendapatan daerah Kabupaten Sumbawa Barat tahun 2006 adalah sebagai berikut :

$$
\begin{aligned}
& \text { rzov6 }=\frac{\text { RoyaltiYT NNT tahun } 2006}{\text { Pendapatan daerah tahun } 2006} \times 100 \% \\
& \text { P2006 }=\frac{47.541 .574 .848}{219.007 .101 .868} \times 100 \% \\
& \text { P } 2006=\mathbf{2 1 , 7 0 \%}
\end{aligned}
$$

Berdasarkan perhitungan di atas terlihat bahwa untuk mengetahui besarnya kontribusi royalti PT NNT terhadap pendapatan daerah Kabupaten Sumbawa Barat pada tahun 2006 yaitu dengan memperbandingkan besarnya nilai royalti yang diberikan 
oleh PT NNT melalui Dana Bagi Hasil (DBH) adalah sebesar Rp. 47.541.674.848,- dan ketika dibandingkan dengan pendapatan daerah Kabupaten Sumbawa Barat pada tahun 2006 sebesar Rp 219.007.101.868 maka besarnya kontribusi yang diberikan oleh royalti PT NNT sebesar 21,70 persen.

Berdasarkan formula yang sama maka perhitungan kontribusi royalti PT. NNT terhadap pendapatan daerah Kabupaten Sumbawa Barat tahun 2007 adalah sebagai berikut :

$$
\begin{aligned}
& \text { YZOU }=\frac{\text { Royalti PT NNT tahun } 2007}{\text { Pendapatan daerah tahun } 2007} \times 100 \% \\
& \mathrm{Y} 200 /=\frac{44.100 .844 .542}{321.226 .172 .886} \times 100 \% \\
& \mathrm{P} 2007=\mathbf{1 3 , 6 9 \%}
\end{aligned}
$$

Perhitungan di atas menunjukkan bahwa untuk mengetahui besarnya kontribusi royalti PT. NNT terhadap pendapatan daerah Kabupaten Sumbawa Barat pada tahun 2007 yaitu dengan memperbandingkan besarnya nilai royalti yang diberikan oleh PT. NNT melalui Dana Bagi Hasil (DBH) adalah sebesar Rp 44.100.844.542,- dan ketika dibandingkan dengan pendapatan daerah Kabupaten Sumbawa Barat pada tahun 2007 sebesar Rp. 321.926.172.886,maka besarnya kontribusi yang diberikan oleh royalti PT. NNT sebesar 13,69 persen. Angka ini menurun disebabkan oleh kurang transparannya alokasi dan pemanfaatan royalti PT. NNT oleh pihak yang berkepentingan.

Selanjutya dapat dilakukan perhitungan kontribusi royalti PT. NNT terhadap pendapatan daerah Kabupaten Sumbawa Barat tahun 2008 adalah sebagai berikut :

$$
\begin{aligned}
& \text { P2008 }=\frac{\text { RoyaltiPT NNT tahun 2008 }}{\text { Pendapatan daerah tahun } 2008} \times 100 \% \\
& \text { P 2008 }=\frac{43.619 .370 .000}{345.165 .134 .203} \times 100 \%
\end{aligned}
$$

$\mathrm{P} 2008=\mathbf{1 2 , 6 4} \%$

Berdasarkan perhitungan di atas terlihat bahwa untuk mengetahui besarnya kontribusi royalti PT. NNT terhadap pendapatan daerah Kabupaten Sumbawa Barat pada tahun 2008 yaitu dengan memperbandingkan besarnya nilai royalti yang diberikan oleh PT NNT melalui Dana Bagi Hasil (DBH) adalah sebesar Rp. 43.619.370.000,dan ketika dibandingkan dengan pendapatan daerah Kabupaten Sumbawa Barat pada tahun 2008 sebesar Rp.345.165.134.203,- maka besarnya kontribusi yang diberikan oleh royalti PT. NNT sebesar 12,64 persen.

Berdasarkan formula tersebut diatas juga maka dapat dilakukan perhitungan kontribusi royalti PT. NNT terhadap pendapatan daerah Kabupaten Sumbawa Barat tahun 2009 adalah sebagai berikut :

$$
\begin{aligned}
& \text { P2009 }=\frac{\text { Royalti YI NNI tahun 2009 }}{\text { Pendapatan daerah tahun 2009 }} \times 100 \% \\
& \text { P } 2009=\frac{47.576 .426 .813}{345.165 .134 .203} \times 100 \mathrm{~W} \\
& \text { P } 2009=\mathbf{1 3 , 7 8 \%}
\end{aligned}
$$

Berdasarkan perhitungan diatas terlihat bahwa untuk mengetahui besarnya kontribusi royalti PT NNT terhadap pendapatan daerah Kabupaten Sumbawa Barat pada tahun 2009 yaitu dengan memperbandingkan besarnya nilai royalti yang diberikan oleh PT NNT melalui Dana Bagi Hasil (DBH) adalah sebesar Rp. 47.576.426.813,dan ketika dibandingkan dengan pendapatan daerah Kabupaten Sumbawa Barat pada tahun 2009 sebesar Rp.345.165.134.203,- maka besarnya kontribusi yang diberikan oleh royalti PT. NNT sebesar 13,78 persen.

Perhitungan kontribusi royalti PT. NNT terhadap pendapatan 
daerah Kabupaten Sumbawa Barat tahun 2010 adalah sebagai berikut :

$$
\begin{aligned}
& \text { P2OIU }=\frac{\text { Royalti YI NNI tahun } 2010}{\text { Pendapatan daerahtahun } 2010} \times 100 \% \\
& \text { P } 2010=\frac{91.208 .939 .206}{422.136 .168,603} \times 100 \% \\
& \text { P } 2010=\mathbf{2 1 , 2 5 \%}
\end{aligned}
$$

Berdasarkan perhitungan di atas terlihat bahwa untuk mengetahui besarnya kontribusi royalti PT NNT terhadap pendapatan daerah Kabupaten Sumbawa Barat pada tahun 2010 yaitu dengan membandingkan besarnya nilai royalti yang diberikan oleh PT. NNT melalui Dana Bagi Hasil (DBH) adalah sebesar Rp. 91.208.939.206,- dibandingkan dengan pendapatan daerah Kabupaten Sumbawa Barat pada tahun 2010 sebesar Rp. 429.136.768,603 maka besarnya kontribusi yang diberikan oleh royalti PT. NNT sebesar 21,25 persen.

Selanjutnya perhitungan kontribusi royalti PT. NNT terhadap pendapatan daerah Kabupaten Sumbawa Barat tahun 2011 adalah sebagai berikut :

$$
\begin{aligned}
& \text { P2011 }=\frac{\text { Royalti PI NNI tahun } 2011}{\text { Pendapatan daeraht tahun } 2011} \times 100 \% \\
& \text { P } 2011-\frac{51.081 .660 .5 / 1}{528.223 .013 .357} \times 100 \% \\
& \text { P } 2011=\mathbf{1 1 , 5 6 \%}
\end{aligned}
$$

Berdasarkan perhitungan di atas terlihat bahwa untuk mengetahui besarnya kontribusi royalti PT NNT terhadap pendapatan daerah Kabupaten Sumbawa Barat pada tahun 2011 yaitu dengan membandingkan besarnya nilai royalti yang diberikan oleh PT. NNT melalui Dana Bagi Hasil (DBH) adalah sebesar Rp. 61.081.866.371,-- dan ketika dibandingkan dengan pendapatan daerah Kabupaten Sumbawa Barat pada tahun 2011 sebesar Rp528.223.013.357,- maka besarnya kontribusi yang diberikan oleh royalti PT. NNT sebesar 11,56 persen.

Tahun terakhir berdasarkan formula di atas maka dapat dilakukan perhitungan kontribusi royalti PT. NNT terhadap pendapatan daerah Kabupaten Sumbawa Barat tahun 2012 adalah sebagai berikut :

$$
\begin{aligned}
& \mathrm{r} Z 012=\frac{\text { Royalt PT NNT tahun } 2012}{\text { Pendapatan daerah tahun } 2012} \times 100 \% \\
& \mathrm{P} 2012=\frac{42.275 .234 .607}{517.620 .500 .968} \times 100 \% \\
& \text { P } 2012=\mathbf{0 8 , 1 6 \%}
\end{aligned}
$$

Berdasarkan perhitungan di atas terlihat bahwa untuk mengetahui besarnya kontribusi royalti PT NNT terhadap pendapatan daerah Kabupaten Sumbawa Barat pada tahun 2012 yaitu dengan memperbandingkan besarnya nilai royalti yang diberikan oleh PT NNT melalui Dana Bagi Hasil (DBH) adalah sebesar Rp. 42.275.234.607,- dan ketika dibandingkan dengan pendapatan daerah Kabupaten Sumbawa Barat pada tahun 2012 sebesar Rp. 571.620.300.968,maka besarnya kontribusi yang diberikan oleh royalti PT. NNT sebesar 08,16 persen.

Berdasarkan uraian di atas maka kondisi kontribusi royalti PT. NNT terhadap pendapatan daerah Kabupaten Sumbawa Barat sebagaimana diuraikan dalam tabel 4.1. berikut :

Tabel 4.1.

Besarnya Kontribusi Royalti PT NNT Terhadap Pendapatan Daerah Kabupaten Sumbawa Barat Tahun 2006-2012

\begin{tabular}{|c|c|c|}
\hline No & Tahun & $\begin{array}{c}\text { Kontribusi } \\
\text { Royalti PT NNT }\end{array}$ \\
\hline 1 & 2006 & $21,70 \%$ \\
\hline 2 & 2007 & $13,69 \%$ \\
\hline 3 & 2008 & $12,64 \%$ \\
\hline 4 & 2009 & $13,78 \%$ \\
\hline 5 & 2010 & $21,25 \%$ \\
\hline 6 & 2011 & $11,56 \%$ \\
\hline 7 & 2012 & $08,16 \%$ \\
\hline
\end{tabular}

Sumber : Data DPPKA Kabupaten Sumbawa Barat, diolah (2012) 
Berdasarkan besarnya kontribusi yang ditunjukkan oleh tabel 6.1. di atas terlihat bahwa tahun 2006 kontribusi royalti PT. NNT terhadap pendapatan daerah Kabupaten Sumbawa Barat tahun 2006 sebesar 21,70 persen akan tetapi terjadi penurunan kontribusinya tahun 2007 sebesar 13,69 persen dan demikian halnya juga pada tahun 2008 menurun 1,05 persen dari tahun 2008 sebesar 12,64 persen. Kemudian pada tahun 2009 kontribusi royalti PT. NNT naik 13,78 persen dan pada tahun 2010 naik pesat mendekati tahun 2006 sebesar 21,25 persen kontribusi pada tahun ini memberikan nilai kontribusi pada urutan kedua setelah tahun 2006 dan tahun 2011 dan tahun 2012 kontribusinya justru turun drastis dengan kontribusi hanya 11,56 persen dan 08,16 persen.

\section{KESIMPULAN, IMPLIKASI, SARAN, DAN BATASAN}

\section{Kesimpulan}

Berdasarkan hasil analisa yang telah dilakukan pada pembahasan sebelumnya, maka kesimpulan yang dapat diambil adalah sebagai berikut :

Berdasarkan hasil analisis kontribusi royalti PT NNT terhadap pendapatan daerah Kabupaten Sumbawa Barat Tahun 2006-2012 maka kontribusi terbesar terjadi pada tahun 2006 sebesar 21,70 persen, hal ini disebabkan karena pembagian Dana Bagi Hasil (DBH) dari iuran tetap eksplorasi dan eksploitasi hasil tambang Kabupaten Sumbawa Barat mendapatkan kontribusi pertama setelah memekarkan diri dari Kabupaten Sumbawa.

Kontribusi royalti PT. NNT terhadap pendapatan daerah Kabupaten Sumbawa Barat bersifat naik turun yang ditunjukkan oleh nilai kontribusi pada tahun 2006 sebesar 21,70 persen, tahun 2007 sebesar 13,69 persen, pada tahun 2008 menurun 1,05 persen dari tahun 2008 sebesar 12,64 persen. Kemudian pada tahun 2009 kontribusi royalti PT. NNT naik 13,78 persen dan pada tahun 2010, tahun 2011 dan tahun 2012 kontribusi sebesar 11,56 persen dan 08,16 persen. Penurunan dan kenaikan ini lebih disebabkan oleh kurang transparannya alokasi dan pemanfaatan royalti PT. NNT oleh pihak yang berkepentingan.

\section{Saran}

Berdasarkan kesimpulan di atas maka beberapa saran yang dapat dituliskan adalah sebagai berikut :

Pemerintah Kabupaten

Sumbawa Barat pada masa yang akan datang diharapkan dapat lebih memperhatikan besarnya kontribusi yang diberikan oleh PT NNT yaitu pada tahun 2010 agar dapat meningkatkan kesejahteraan masyarakat Kabupaten Sumbawa Barat.

Pemerintah Kabupaten Sumbawa Barat hendaknya memantau dengan seksama tujuan pemberian royalti PT NNT bagi masyarakat terutama dalam peningkatan kemampuan bekerja dan lapangan usaha menuju masyarakat yang produktif dengan kesejahteraan yang semakin membaik.

\section{DAFTAR PUSTAKA}

Hartono, Budi. (1999). Kontribusi IHH dan IHPH terhadap Pendapatan Daerah propinsi Kaltim. Jurnal Research Gate. Publikasi/5092856

Isir, Kristian. (2003). Kontribusi PAD terhadap APBD di Kabupaten Merauke tahun 1994/1995 Jurnal Research Gate. Publikasi/5092879675 
Koswara,E. (2000). Menyongsong

Pelaksanaan Otonomi Daerah

Berdasarkan Undang-Undang Nomor 22 Tahun 1999, Analisis CSIS Tahun XXIX/2000 Nomor 1

Kuncoro, Mudrajat. (1997).

Desentralisasi Fiskal di Indonesia.

Prisma No. 4 :3-17. Jakarta

Lukman Malanuang. (2002). Analisis

Dampak Ekonomi dan Sosial

Tambang Emas dan Tembaga bagi

Masyarakat Komunal dan

Pembangunan Wilayah Propinsi Nusa

Tenggara Barat (Studi Kasus Proyek

Batu Hijau PT Newmont Nusa

Tenggara di Kabupaten Sumbawa

Barat (Tesis). Bogor. Program

Pascasarjana. Institut Pertanian Bogor (IPB).

Mahi, Raksasa. (2000). Prospek Desentralisasi di Indonesia ditinjau dari segi Pemerataan antar daerah dan peningkatan efisiensi, Analisis CSIS

Tahun XXIV/2000 No.1,54-56.

Octora W,Maya. (2006). Kontribusi

Sektor Pariwisata Terhadap

Pendapatan Asli Daerah Kabupaten

Pacitan tahun 1999-2005. Jurnal

Research. Gate, Publikasi.

Peraturan Menteri Dalam Negeri

Nomor 13 tahun 2006 tentang

pedoman Pengelolaan Keuangan

Daerah

Peraturan Pemerintah Republik

Indonesia Nomor 55 Tahun 2005

tentang Dana Perimbangan

Ratrisari, Dinardi dan Wahyono, Hadi. (2002). Melakukan penelitian dengan judul Kontribusi Objek Wisata di Kota Yogyakarta Terhadap Pendapatan

Asli Daerah.
Spillane, J James. (1994) Pariwisata Indonesia Siasat Ekonomi dan

Rekayasa Kabudayaan. Yogyakarta:

Kanisius

Syafruddin. (2002). Peranan Potensi

Retribusi Pasar Sebagai Sumber

Pendapatan Asli Daerah di

Kabupaten Sleman. Yogyakarta: FE

UII

Undang-Undang Nomor 17 Tahun

2003 Tentang Keuangan Negara.

Undang-Undang Nomor 32 Tahun

2004 Tentang Pemerintahan Daerah.

Undang-Undang Nomor 33 Tahun

2004 Tentang Perimbangan Keuangan

Antara Pemerintah Pusat dan

Pemerintah Daerah. 